\title{
Compositional responses of bacterial communities to redox gradients and grazing in the anoxic Cariaco Basin
}

\author{
Xueju Lin ${ }^{1,4, *}$, Mary I. Scranton ${ }^{1}$, Ramon Varela ${ }^{2}$, Andrei Chistoserdov ${ }^{3}$, \\ Gordon T. Taylor ${ }^{1}$ \\ ${ }^{1}$ Marine Sciences Research Center, Stony Brook University, Stony Brook, New York 11794-5000, USA \\ ${ }^{2}$ Estacion de Investigaciones Marinas de Margarita, Fundacion La Salle de Ciencias Naturales, Apartado 144, \\ Punta de Piedras, Edo, Nueva Esparta, Venezuela \\ ${ }^{3}$ Department of Biology, University of Louisiana at Lafayette, Lafayette, Louisiana 70504, USA \\ ${ }^{4}$ Present address: Stroud Water Research Center, Avondale, Pennsylvania 19311, USA
}

\begin{abstract}
During a May 2005 cruise, depth-dependent distributions of bacterial populations and their responses to predator exclusion were investigated in the anoxic Cariaco Basin, Venezuela. Community structure was assessed using fluorescence in situ hybridization (FISH) and terminal restriction fragment length polymorphism (T-RFLP) of 16S rRNA genes. FISH combined with microautoradiography was used to determine single-cell activity of heterotrophic bacterial populations provided with ${ }^{3} \mathrm{H}$-leucine substrate. FISH and T-RFLP patterns clearly illustrated shifts in bacterial community composition as waters transitioned from oxic to anoxic conditions at depth. Predator-exclusion experiments were conducted at 3 depths across the redoxcline. Although richness of bacterial operational taxonomic units (OTUs) was initially reduced at all 3 depths $(250,270,400 \mathrm{~m})$ as a likely consequence of confinement, distinct responses of individual OTUs to predator exclusion were detected in T-RFLP patterns. FISH analyses also detected very consistent responses of $\alpha-, \beta-, \gamma-$, and $\varepsilon$-proteobacteria to predator exclusion. The $\alpha$ - and $\beta$-proteobacteria became more prevalent in controls than in 'predator-free' samples $(<1.6 \mu \mathrm{m}$ filtrate) over time. In contrast, $\gamma$ - and $\varepsilon$-proteobacteria gained prevalence in 'predator-free' samples. Interestingly, abundances of $\beta$-proteobacteria dramatically declined over time in both controls and predator-free treatments, and none actively assimilated ${ }^{3} \mathrm{H}$-leucine (MICRO-FISH). Among ${ }^{3} \mathrm{H}$-leucine-assimilating cells in control samples at $270 \mathrm{~m}$, $\alpha-, \gamma-$ and $\varepsilon$-proteobacteria accounted for 12,38 , and $14 \%$ of ${ }^{3} \mathrm{H}$-leucine active cells, respectively. Taxonomic distributions of ${ }^{3} \mathrm{H}$-leucine-assimilating cells in predator-exclusion treatments did not detectably differ from controls. Overall, results demonstrated that redox gradients structured microbial communities and that predator exclusion significantly altered bacterial abundances and community composition.
\end{abstract}

KEY WORDS: Redox gradients · Grazing $\cdot$ Bacteria $\cdot$ Cariaco Basin $\cdot$ FISH $\cdot$ T-RFLP Resale or republication not permitted without written consent of the publisher

\section{INTRODUCTION}

Top-down (predation by protozoa and viral-induced lysis) and bottom-up (availability of limiting resources) controls are the most critical ecological and physiological factors that determine microbial biodiversity in pelagic ecosystems (Torsvik et al. 2002). The balance between limiting resource availability and mortality determines net production of total bacterial biomass. Selective grazing determines how biomass is distributed among morphological and functional groups, and host specificity of viruses can determine how functional groups are parsed among species (Torsvik et al. 2002, Pernthaler 2005). Generally, predation by protis- 
tan bacterivores affects size, morphology, physiology and species interactions of surviving bacterial populations (Hahn \& Hofle 2001, Pernthaler 2005). In oxic waters, effects of grazing on structuring microbial community have been fairly well studied (Suzuki 1999, Hahn \& Hofle 2001, Sherr \& Sherr 2002, Beardsley et al. 2003, Massana \& Jürgens 2003, Pernthaler 2005), but they are less understood in suboxic and anoxic waters. While anaerobic food webs are expected to have lower trophic transfer efficiency and support fewer trophic levels, fundamental differences in grazing effects might not be expected between oxic and anoxic environments (Fenchel \& Finlay 1994, Biagini et al. 1998, Pedros-Alio et al. 2000). Previous work in the anoxic Cariaco Basin has revealed an active microbial loop in the redoxcline, where diverse bacteria, viral parasites and protozoa participate in microaerophilic and anaerobic food webs (Madrid et al. 2001, Stoeck et al. 2003, Taylor et al. 2003, 2006). Knowledge of predation effects on specific bacterial groups can further our understanding of how individual microbial populations influence carbon transformations and elemental cycling in transitional waters between oxic and anoxic systems.

The redoxcline of the Cariaco Basin contains strong geochemical gradients (Richards 1975, Ho et al. 2004). Briefly, nitrate concentrations usually exhibit maxima around $150 \mathrm{~m}$, and become undetectable very near the $\mathrm{O}_{2} / \mathrm{H}_{2} \mathrm{~S}$ interface (usually between 250 and $350 \mathrm{~m}$ ), where $\mathrm{O}_{2}$ and sulfide concentrations approach zero (Ho et al. 2004). Below this depth horizon, $\mathrm{NH}_{4}{ }^{+}$ steadily increases toward the seafloor, reaching $24 \mu \mathrm{M}$ (Taylor et al. 2001). Abiotic and biotic metal redox reactions occur between 250 and $400 \mathrm{~m}$, while sulfate reduction is likely to occur at significant rates only below the $\mathrm{O}_{2} / \mathrm{H}_{2} \mathrm{~S}$ interface (Ho et al. 2004). This obvious zonation of electron donors and acceptors organizes bacterial ecotypes residing here into distinct assemblages (Madrid et al. 2001, Taylor et al. 2006). Profiling bacterial community composition along this redoxcline can enhance our understanding of how bacterial assemblages mediate biogeochemical processes. However, knowledge of the dynamic interplay between bacteria, predator and resource availability is needed to assemble all this information into a rational model that will adequately describe the anaerobic microbial loop.

In this study, microbial assemblages throughout the water column of the Cariaco Basin were characterized using fluorescence in situ hybridization (FISH) and terminal restriction fragment length polymorphism (T-RFLP) analyses. Predator-exclusion experiments were performed with samples from the redoxcline to examine responses of complex bacterial communities to predation. In addition, FISH com- bined with microautoradiography (MICRO-FISH) was used to assess group-specific ${ }^{3} \mathrm{H}$-leucine assimilation activity and population responses to predator exclusion.

\section{MATERIALS AND METHODS}

Field site, sampling and biogeochemical measurements. Bacterioplankton samples were collected from 18 depths on 22 May 2005 (CAR-112) at the CARIACO time series station $\left(10.50^{\circ} \mathrm{N}, 64.66^{\circ} \mathrm{W}\right)$, located in the eastern sub-basin of the Cariaco system, Venezuela (Muller-Karger et al. 2001). Samples for FISH were withdrawn from 81 Teflon-lined Niskin bottles under $\mathrm{N}_{2}$ atmosphere, and fixed overnight with formaldehyde solution (final concentration $2 \%[\mathrm{v} / \mathrm{v}]$ ) passing through a $0.22 \mu \mathrm{m}$ pore-size cellulosic membrane filter (47 mm, Osmonics). Duplicate 20 to $60 \mathrm{ml}$ samples were filtered onto white polycarbonate membranes (Millipore, type GTTP, $0.2 \mu \mathrm{m}$ pore size, $47 \mathrm{~mm}$ diameter), washed with $20 \mathrm{ml}$ sterile distilled water, and stored at $-20^{\circ} \mathrm{C}$. For DNA samples, triplicate $60 \mathrm{ml}$ water samples were filtered through $0.2 \mu \mathrm{m}$ pore-size $13 \mathrm{~mm}$ Millipore Express ${ }^{\circledR}$ membranes (type GPWP) in Swinnex $13^{\circledR}$ filter holders (Millipore) using a polypropylene syringe. Filters were placed in $0.6 \mathrm{ml}$ sterile microcentrifuge tubes, immersed in $180 \mu \mathrm{l}$ of DNA lysis buffer (20 mM Tris-HCl, pH 8.0, 2 mM EDTA, pH 8.0, $1.2 \%$ Triton $\mathrm{X}-100)$ and stored at $-20^{\circ} \mathrm{C}$ before DNA extraction (Suzuki et al. 2001).

Discrete samples for $\mathrm{O}_{2}, \mathrm{H}_{2} \mathrm{~S}$, heterotrophic and chemoautotrophic production were taken from the same Niskin bottles. Heterotrophic bacterial production (HBP) and chemoautotrophic production were determined by assimilation of ${ }^{3} \mathrm{H}$-leucine into protein and ${ }^{14} \mathrm{C}$-bicarbonate into particles, respectively. Details of these methods have been described previously (Taylor et al. 2001). Standard DAPI-stained slides were prepared on dark, $0.2 \mu \mathrm{m}$ pore-size Poretics polycarbonate membranes for enumeration of bacteria (Porter \& Feig 1980). For flagellate enumeration and sizing, $100 \mathrm{ml}$ of formaldehyde-preserved samples was stained with acridine orange for $5 \mathrm{~min}$ and collected on $0.8 \mu \mathrm{m}$ pore-size Poretics polycarbonate membrane filters. Subsequently, 20 to 30 fields were enumerated by epifluorescence microscopy. Microscopic images were captured with an Optronics MagnaFire CCD camera, and processed in ImagePro Plus version 4.5 (Media Cybernetics). Fluorescence threshold was manually tuned to conform to cell boundaries. Mean diameter of flagellates was defined as average length of diameters measured at $2^{\circ}$ intervals that passed through the object's centroid, following the software manual. 
Predator-exclusion and ${ }^{3} \mathrm{H}$-leucine assimilation experiments. Water samples from $250 \mathrm{~m}$ (the shallowest appearance of sulfide), $270 \mathrm{~m}$ (mid-water particle maximum), and $400 \mathrm{~m}$ (the bottom of the redoxcline) were first transferred from Niskin bottles by overfilling 11 glass dispensing bottles to eliminate any headspace. Subsamples were then transferred under $\mathrm{N}_{2}$ pressure into $50 \mathrm{ml}$ serum bottles with several seconds of overflow, and sealed using butyl rubber septa with no headspace. To exclude predators, water from the dispensing bottle was passed directly through a $47 \mathrm{~mm}$ in-line filtration system containing a glass fiber filter (1.6 $\mu \mathrm{m}$ pore-size, type APFA, Millipore) on its way to the serum bottles. More than $93 \%$ of flagellated protozoa in these samples were in the diameter range of 2 to $7 \mu \mathrm{m}$, with a small portion of them having a mean diameter between 1.6 and $2.0 \mu \mathrm{m}$. Therefore, a few small flagellated protozoa may have passed through APFA filters, but flagellate populations in predatorexclusion treatments were considered to be negligible. Sample volume limitations precluded enumeration of flagellate abundances throughout the entire experiments. One time-zero sample $\left(t_{0}\right)$ from control and predator-exclusion treatments for each depth was processed immediately for FISH and DNA extraction. All samples were incubated in a water bath at in situ temperature $\left(17 \pm 2^{\circ} \mathrm{C}\right)$ in darkness, and were sacrificed at 1, 2, 4, and $8 \mathrm{~d}$.

For substrate assimilation experiments (MICROFISH), $\mathrm{N}_{2}$-purged ${ }^{3} \mathrm{H}$-leucine (final $\sim 0.5 \mu \mathrm{Ci} \mathrm{ml}^{-1}$, specific activity $150 \mathrm{Ci} \mathrm{mmol}^{-1}$, Amersham) was injected into serum bottles filled with whole water or $1.6 \mu \mathrm{m}$ filtrate samples from $270 \mathrm{~m}$. Only 1 depth received microautoradiographic analysis owing to loss of tracer. The $t_{0}$ samples were killed with $2 \%$ formaldehyde prior to addition of radiolabel. To minimize possible uptake of radioactive by-products by non-target organisms, samples for substrate assimilation were terminated after $1 \mathrm{~d}$ of incubation at $17 \pm 2^{\circ} \mathrm{C}$.

To terminate incubations, $10 \mathrm{ml}$ aliquots from each bottle were fixed with final $2 \%$ formaldehyde and filtered through $25 \mathrm{~mm} 0.2 \mu \mathrm{m}$ GTTP membrane filters (Millipore) for FISH, and $30 \mathrm{ml}$ aliquots were immediately filtered through $0.2 \mu \mathrm{m}$ pore-size $13 \mathrm{~mm}$ Millipore Express membrane (type GPWP) as above for DNA samples. Samples with radiolabel were fixed with final $2 \%$ formaldehyde and filtered through $25 \mathrm{~mm} 0.2 \mu \mathrm{m}$ GTTP membrane filters for MICROFISH. First-order rates of change $\left(k, \mathrm{~d}^{-1}\right)$ in bacterial populations were calculated assuming exponential growth or loss: i.e. $k=(1 / t) \ln \left(N_{2} \times N_{0}\right)$, where $N_{0}$ and $N_{2}$ are the abundances of cells (cells ml- ${ }^{-1}$ ) at the beginning and at the end of $2 \mathrm{~d}$ incubations, respectively, and $t$ is the incubation duration in days. In many instances, $k$ values were negative as populations diminished. Positive values of $k$ determined by this method are conservative estimates of growth because flexible protozoa may have passed through the APFA filter and viruses were undoubtedly present, causing some bacterial mortality during incubations.

FISH with monolabeled probes. The protocol described by Pernthaler et al. (2001) was used for FISH measurements. Owing to limited sample availability (6 filter wedges for many samples) in this study, only 6 oligonucleotide probes were used: EUB338 (5'GCTGCCTCCCGTAGGAGT-3', specific for domain Eubacteria; Amann et al. 1990); ALF968 (5'-GGTAAGGTTCTGCGCGTT-3', specific for $\alpha$-proteobacteria; Neef 1997); BET42a (5'-GCCTTCCCACTTCGTTT-3', specific for $\beta$-proteobacteria; Manz et al. 1992); GAM42a (5'-GCCTTCCCACATCGTTT-3', specific for $\gamma$-proteobacteria; Manz et al. 1992); EPS682 (5'-CGGATTTTACCCCTACAC-3', specific for $\varepsilon$-proteobacteria; this study); and NONEUB (5'-ACTCCTACGGGAGGCAGC-3', nonsense sequence as negative control; Wallner et al. 1993). All probes were commercially synthesized and labeled with the indocarbocyanine dye CY3 (Integrated DNA Technologies). Specificity of the EPS682 probe and hybridization conditions for all probes were optimized according to Lin et al. (2006). Each membrane filter (47 or $25 \mathrm{~mm}$ ) was cut into 16 (or 6) wedges. Individual wedges were covered with $50 \mu \mathrm{l}$ of hybridization solution containing $0.9 \mathrm{M}$ $\mathrm{NaCl}, 20 \mathrm{mM}$ Tris/HCl (pH 7.5), $0.01 \%$ sodium dodecyl sulfate (SDS), $35 \%$ formamide, and $2.5 \mathrm{ng} \mathrm{pl}^{-1}$ of CY3labeled oligonucleotide, and then incubated at $46^{\circ} \mathrm{C}$ for $120 \mathrm{~min}$ in the humidity-equilibrated chamber of an InSlide-Out hybridization oven (Boekel Scientific).

After hybridization, filter wedges were quickly transferred to a pre-warmed $\left(48^{\circ} \mathrm{C}\right)$ vial containing $50 \mathrm{ml}$ of washing solution $(80 \mathrm{mM} \mathrm{NaCl}, 20 \mathrm{mM}$ Tris$\mathrm{HCl}[\mathrm{pH} 7.4], 5 \mathrm{mM}$ EDTA, and $0.01 \%$ SDS) and were incubated without agitating at $48^{\circ} \mathrm{C}$ for $30 \mathrm{~min}$. Filter wedges were dried on Whatman $3 \mathrm{M}$ blotting paper, and mounted on slides with Citifluor AF1 containing $1.0 \mathrm{\mu g} \mathrm{ml}^{-1}$ DAPI. Slides were stored in the dark at $-20^{\circ} \mathrm{C}$ and examined using a Zeiss Axioskop epifluorescence microscope equipped with an $\mathrm{HBO} 50 \mathrm{~W} \mathrm{Hg}$ vapor lamp, appropriate filter sets for CY3 and DAPI dyes, a $100 \times$ objective, an Optronics MagnaFire CCD camera, and an ImagePro 4.5 image analysis system. More than 20 fields or 500 DAPI-stained particles were counted per filter section.

Microautoradiography combined with FISH. Autoradiographic procedures were performed with NTB-2 emulsion (Kodak) (Carman 1993). The autoradiographic development was conducted in a dark room by transferring previously hybridized filter sections onto slides coated with diluted emulsion (2 parts emulsion and 1 part Milli-Q water). Subsequently, the slides 
were placed in an opaque box with silicon desiccant and exposed at $4^{\circ} \mathrm{C}$ for $48 \mathrm{~h}$. The optimum exposure time for the samples was found to be $2 \mathrm{~d}$ in a test series ranging from 1 to $6 \mathrm{~d}$. Slides were developed with Dektol developer (1:1 dilution with Milli-Q water) for 2 min, rinsed with Milli-Q water for $30 \mathrm{~s}$, and fixed using Kodak fixer for 5 min followed by a Milli-Q water rinse for $10 \mathrm{~min}$. After overnight drying, slides were soaked in $1 \%$ glycerin solution for 2 min. Membranes were then peeled away from the emulsion and cells embedded in emulsion were counterstained with Citifluor AF1 containing $1.0 \mu \mathrm{g} \mathrm{ml}^{-1}$ DAPI. Silver grains in autoradiographic emulsion were observed microscopically by switching from fluorescence to bright field mode. More than 1000 DAPI-stained cells per sample were examined for silver grain development.

T-RFLP analysis. DNA samples were thawed and incubated with $20 \mathrm{mg} \mathrm{ml}^{-1}$ lysozyme for $1 \mathrm{~h}$ at $37^{\circ} \mathrm{C}$. Subsequently, $1 \mu \mathrm{l}$ of $500 \mu \mathrm{g} \mathrm{ml}^{-1}$ DNase-free RNase I (Roche Molecular Systems) was added and samples were incubated for $5 \mathrm{~min}$ at room temperature. Proteinase $\mathrm{K}\left(25 \mu \mathrm{l}\right.$ of $\left.25 \mathrm{mg} \mathrm{ml}^{-1}\right)$ was then added, and samples were subsequently treated according to the DNeasy ${ }^{\circledR}$ tissue kit protocol for Gram-positive bacteria (Qiagen) to guarantee complete lysis of both Gramnegative and Gram-positive bacteria. Extracts from triplicate samples were pooled to limit effects of random extraction bias (Clement et al. 1998). The presence of high-molecular weight DNA (6 to $10 \mathrm{~kb}$ ) was confirmed on $0.8 \%$ agarose gels. The primers used for PCR amplification of bacterial 16S rRNA genes were 63F-FAM (5'-CAGGCCTAACACATGCAAGTC3') (Marchesi et al. 1998) and 778R (5'-AGGGTATCTAATCCTGTTTGC-3') (Marchesi et al. 1998, Rosch \& Bothe 2005). 63F-FAM was 5 '-end labeled with phosphoramidite fluorochrome 5-carboxyfluorescein (Integrated DNA Technologies). PCR mixtures (50 $\mu$ l final volume) contained $1 \times$ PCR buffer (Stratagene), $250 \mu \mathrm{M}$ of each deoxynucleoside triphosphate (Roche Molecular Systems), $200 \mathrm{nM}$ of primers, and $1.25 \mathrm{U}$ SureStart Taq DNA polymerase (Stratagene). Approximately $1 \mathrm{ng}$ quantities of DNA samples were added to each PCR reaction. PCR was performed in a Stratagene Mx3000p real-time PCR system with an initial denaturation step of $95^{\circ} \mathrm{C}$ for $10 \mathrm{~min}$, followed by 30 cycles of $95^{\circ} \mathrm{C}$ for $30 \mathrm{~s}, 55^{\circ} \mathrm{C}$ for $30 \mathrm{~s}$, and $72^{\circ} \mathrm{C}$ for $1 \mathrm{~min}$ and a final extension at $72^{\circ} \mathrm{C}$ for $7 \mathrm{~min}$.

Five replicate PCR products per sample were pooled and purified with a QIAquick PCR purification kit (Qiagen) according to the manufacturer's instructions. The amplification products were visualized by electrophoresis on a $1.0 \%$ agarose gel in $1 \times$ TAE $(40 \mathrm{mM}$ Tris-acetate, $1 \mathrm{mM}$ EDTA) containing ethidium bromide $\left(0.50 \mathrm{mg} \mathrm{ml}^{-1}\right)$. Concentrations of PCR products were measured fluorometrically by PicoGreen staining
(Molecular Probes) with a Fluorescence HPLC monitor (RF-551, Shimadzu) according to the manufacturer's specifications.

Restriction digests were standardized and replicated using $100 \mathrm{ng}$ of purified PCR product for each sample. They were performed with the restriction endonuclease Alu I (AG/CT) (Promega) and associated buffers under conditions recommended by the manufacturer. For detailed T-RFLP pattern analyses of 250, 270 and $400 \mathrm{~m}$ samples, additional restriction digestions were performed with 4 separate reactions per sample, using restriction endonucleases Msp I (C/CGG), Rsa I (GT/AC) (Promega), Mvn I (CG/CG), and Sau96 I (G/GNCC) (Roche Molecular Systems). Digestions were conducted for $6 \mathrm{~h}$ with Alu I, Msp I, and Rsa I and for $1 \mathrm{~h}$ with $\mathrm{Mvn}$ I and $\operatorname{Sau} 96$ I at $37^{\circ} \mathrm{C}$. After ethanol precipitation, the fragment mixtures were dissolved in $10 \mu \mathrm{l}$ of PCR-grade water (Roche Molecular Systems). Prior to capillary electrophoresis, subsamples $(5 \mu \mathrm{l})$ were mixed with Hi-Di formamide $(10 \mu \mathrm{l})$ and a MapMarker Rox1000 size standard $(0.5 \mu l)$ (Bioventure). The analysis of $5 \mu \mathrm{l}$ of this mixture was performed in an ABI 3100 capillary electrophoresis system.

Data processing. Electropherograms were analyzed with GeneMapper version 3.7 software (ABI) for fragment lengths of between 30 and $500 \mathrm{bp}$ and minimum peak height threshold of 50 fluorescence units. Sample profiles with cumulative peak heights less than 10000 total fluorescence units were discarded, and samples were re-run (Blackwood et al. 2003). Peak patterns from different samples were manually aligned by size sorting and manually grouping peaks within $1 \mathrm{bp}$ in fragment length (Clement et al. 1998). Peaks occurring in only one of the duplicate digestions at any depth were not included in the analysis. These peaks were usually less than $8 \%$ of total identified peaks per sample. We use the term operational taxonomic unit (OTU) to refer to individual restriction fragments in T-RFLP patterns, but recognize that each OTU in this case may comprise more than 1 distinct bacterial ribotype (Kent et al. 2003, Rosch \& Bothe 2005).

Phylogenetic assignments were attempted from TRFLP patterns using the terminal restriction fragment identifying program (TReFID), which was developed to identify any of the 17327 GenBank sequences by means of polygons generated from specific terminal restriction fragments (T-RFs) of each bacterium (Rosch \& Bothe 2005). Although identifications of uncultured members of a microbial community are certainly tentative, this in silico approach has been successfully validated with clone libraries from soil samples. It allows retrieval not only of the composition of bacteria down to the genus level, but also of many ribotypes related to a specific organism from environmental samples (Rosch \& Bothe 2005). 
Statistical analysis. T-RFLP patterns from the Alu I digests were converted to a presence/absence matrix and analyzed with PC-ORD version 4 (MjM Software Design). Cluster analysis with the unweighted-pair group method using arithmetic averages (UPGMA) and Jaccard distances were used for grouping samples. The distance in the dendrogram is scaled by Wishart's objective function $(E)$, which is a measure of information loss as agglomeration proceeds and is equal to the sum of errors squared relative to each centroid to the items in that group (McCune \& Grace 2002). The percentage of information remaining can be expressed as 100 (TSS - E)/TSS, where TSS is the total sum of squared deviations from the centroid when all items are fused into 1 group. Therefore, the information remaining is conceptually similar to an $\mathrm{r}^{2}$ value (fraction of variance explained by a regression). In this statistical analysis, effects of PCR bias on peak height are reduced because the approach is based on the presence or absence of peaks only (Blackwood et al. 2003). Bacterial taxon richness, a diversity measure, was based on the number of unique fragments per sample (Liu et al. 1997). The T-RFLP method does not give a complete estimate of bacterial diversity because more than 1 bacterial species may be represented by each distinct terminal fragment, and because many bacteria may not be amplified above the threshold level detected by T-RFLP. However, a strong correlation between the T-RFLP terminal fragment diversity (the number of unique peaks and relative intensity of each peak) and the number of bacterial species present in a given sample was reported elsewhere (Liu et al. 1997). For predator exclusion experiments, paired $t$-tests were performed with SigmaStat 3.1 and used to evaluate differences among variables between control and predator-exclusion treatments.

\section{RESULTS}

\section{Vertical distributions of abiotic and biotic conditions in the water column}

Previous studies of the Cariaco Basin's water column have revealed chemical zonation, which is largely independent of water density structure (Taylor et al. 2001, Ho et al. 2004). During the May 2005 sampling, oxygen concentrations dramatically decreased below the euphotic zone, and reached undetectable levels around $250 \mathrm{~m}$ (Fig. 1a). Below this depth, sulfide increased to a maximum of $62 \mu \mathrm{M}$ at $1300 \mathrm{~m}$, near the Basin's bottom. The highest chemoautotrophic production (361.0 nM C d ${ }^{-1}$ ) was located just below the $\mathrm{O}_{2} / \mathrm{H}_{2} \mathrm{~S}$ interface ( 260 to $\left.320 \mathrm{~m}\right)$, coinciding with a peak in prokaryotic abundances as determined by DAPI counting (Fig. 1a,b). Meanwhile, bacterial heterotrophic production was slightly elevated through the redoxcline, reaching a maximum of $7.5 \mathrm{nM} \mathrm{C} \mathrm{d}^{-1}$

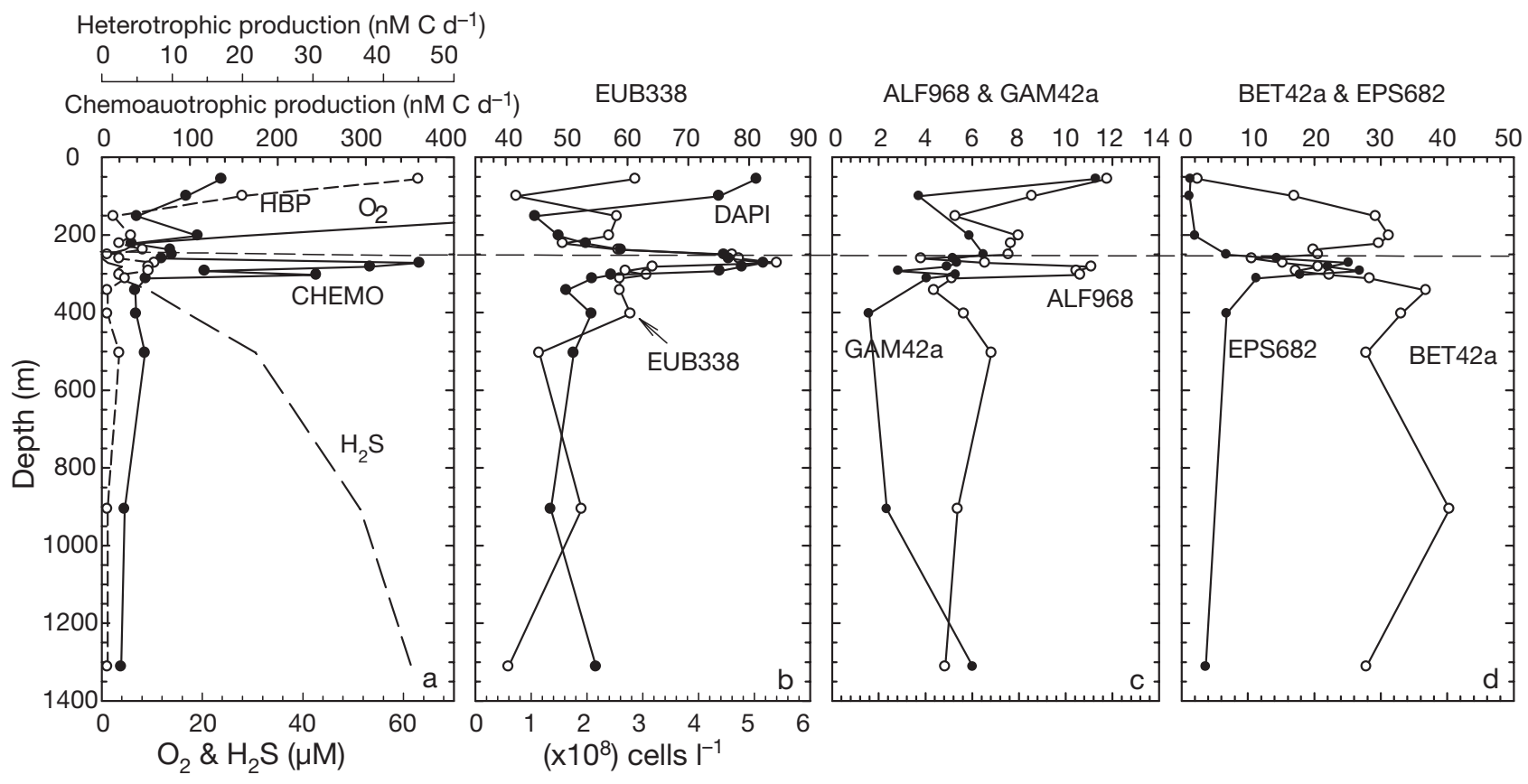

Fig. 1. Vertical distributions of (a) $\mathrm{O}_{2}, \mathrm{H}_{2} \mathrm{~S}$, chemoautotrophic production (CHEMO), heterotrophic bacterial production (HBP), (b) abundance of prokaryotic cells (DAPI counts), and (b,c,d) relative abundances of different phylogenetic groups of bacteria determined by $\mathrm{FISH}_{;} \mathrm{x}$-axes in (b), (c) and (d) are percentages of DAPI counts; dashed horizontal lines indicate depth of shallowest appearance of sulfide 
and amounting to $17 \%$ of the bacterial production in surface waters (Fig. 1a).

FISH surveys clearly illustrated changes in the bacterial community composition throughout the water column. Total prokaryotic abundance varied from $1.1 \times 10^{8}$ to $5.2 \times 10^{8}$ cells $1^{-1}$, with a mid-water peak centered at $270 \mathrm{~m}$ (Fig. 1b). Proportions of DAPI counts visualized by the Eubacteria domain probe (EUB338) varied from $\sim 41 \%$ at 100 and $1300 \mathrm{~m}$ to $85 \%$ at $270 \mathrm{~m}$ (Fig. 1b), with an average value of $59 \pm$ 12\%. Maximum EUB338-positive cell abundances coincided with maximum chemoautotrophic activity,

Fragment size in base pair
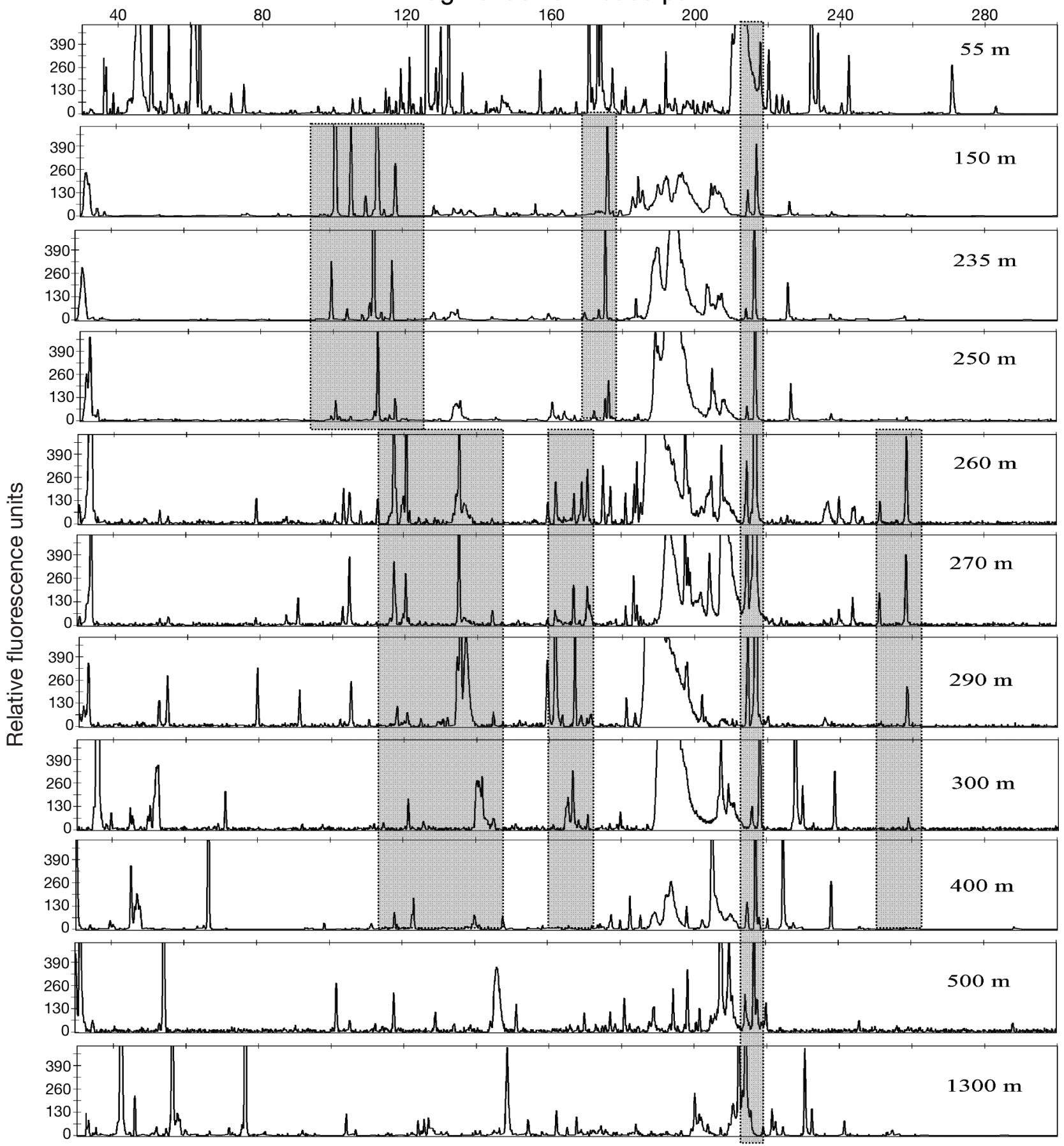

Fig. 2. T-RFLP fingerprints of bacterial communities in samples collected throughout the Cariaco Basin's water column; $x$-axes indicate size of DNA fragments (bp) from amplified 16S rRNA genes after Alu I endonuclease digestion. Gray areas highlight fragment clusters evident at multiple depths 
and EUB338-positive cells significantly decreased below $400 \mathrm{~m}$. Both $\alpha$ - and $\gamma$-proteobacteria (ALF968and GAM42a-positive cells) peaked in surface waters as well as above and below the $\mathrm{O}_{2} / \mathrm{H}_{2} \mathrm{~S}$ interface (Fig. 1c), on average accounting for $7 \pm 2$ and $6 \pm 2 \%$ of DAPI-stained cells throughout the water column, respectively. Below the surface layer, $\beta$-proteobacteria (BET42a-positive cells) became a dominant component of prokaryotic assemblages with a shallow peak at $200 \mathrm{~m}$ and a deeper one at $400 \mathrm{~m}$ (Fig. 1d), accounting for on average $25 \pm 8 \%$ of DAPI counts throughout the water column. In contrast, $\varepsilon$-proteobacteria (EPS682-positive cells) contributed as much as $27 \%$ to the prokaryotic inventory in the redoxcline (250 to $400 \mathrm{~m})$, with a single peak between 260 and $300 \mathrm{~m}$, where $\beta$-proteobacteria accounted for only a minor proportion of DAPI counts (Fig. 1d). Meanwhile, $\varepsilon$-proteobacteria were nearly absent in the upper $200 \mathrm{~m}$ (1 to $2 \%$ ) and contributed only about $5 \%$ to cell inventories in waters below $400 \mathrm{~m}$.

Consistent with FISH profiles, T-RFLP analyses showed shifts in bacterial OTU composition with depth. Based on T-RFLP patterns (Fig. 2) and dendrogram topology derived from cluster analysis (Fig. 3), samples were divided into 4 groups: (1) the photic zone $(55 \mathrm{~m})$, which contains many unique peaks uncommon in depths below; (2) the disphotic zone, including oxic to suboxic depths $(150,235$, and $250 \mathrm{~m})$, where OTUs cluster together in the dendrogram wherein several peaks of sizes 101, 111, 112, 117 and 176 bp are shared and others disappear or decline in the redoxcline; (3) the redoxcline samples $(260,270,290,300$ and $400 \mathrm{~m})$, which share several peaks, notably fragments 135, 217, 238, and 259 bp long; and (4) deeper anoxic waters (500 and $1300 \mathrm{~m}$ ), which share fewer than 10 peaks with overlying waters. Meanwhile, several peaks occur in samples from almost all depths, including fragments 189, 207, 208, 214, 217 and 227 bp in length. Overall, the total number of OTUs per depth varied from 22 to 35 , with a total of 78 unique peaks present in the entire profile.

\section{Effects of predator exclusion and confinement on bacterial community composition}

Prefiltration through an APFA filter permitted passage of 92,86 , and $84 \%$ of total prokaryotic cells in samples from 250, 270, and $400 \mathrm{~m}$, respectively. At initiation of the experiments, abundances of flagellated protozoa in control treatments (whole water) were $1.51 \times 10^{6}, 2.97 \times 10^{6}$ and $3.02 \times 10^{6}$ cells $^{-1}$ at 250 , 270 , and $400 \mathrm{~m}$, respectively. Meanwhile, their mean cell diameters varied only slightly from $2.2 \mu \mathrm{m}$ at $250 \mathrm{~m}$ to $2.3 \mu \mathrm{m}$ at $270 \mathrm{~m}$ and $2.5 \mu \mathrm{m}$ at $400 \mathrm{~m}$. In all samples, bacterial abundances consistently reached their maxima after 2 to $4 \mathrm{~d}$ of incubation, and declined or remained constant after $4 \mathrm{~d}$ (Fig. 4). However, percentages of EUB338-positive cells relative to DAPI counts decreased with incubation time in 250 and $270 \mathrm{~m}$ samples, while dramatically increasing over the time course in the $400 \mathrm{~m}$ samples. Proportions of EUB338positive cells were not significantly different (paired $t$-test, $\mathrm{p}=0.135, \mathrm{n}=10$ ) between control and predatorexclusion samples at any depth (Fig. 4). Net growth rates of bacteria in control samples were higher at $400 \mathrm{~m}\left(1.07 \mathrm{~d}^{-1}\right)$ than at $250 \mathrm{~m}\left(0.27 \mathrm{~d}^{-1}\right)$ or $270 \mathrm{~m}$ $\left(0.34 \mathrm{~d}^{-1}\right)$ (Table 1$)$. Meanwhile, community growth rates in predator-exclusion samples from 270 and $400 \mathrm{~m}$ were on average $30 \%$ higher than those observed in control samples, indicating that filtration released bacteria from grazing pressure and allowed faster accumulation of cells. This response was not observed in the slower-growing community collected from $250 \mathrm{~m}$.

Within bacterial assemblages, distinct responses to predation were most evident after $2 \mathrm{~d}$ using FISH. Mean abundances of $\alpha$-proteobacteria in whole water and predator-exclusion treatments increased from $0.24 \times 10^{8}$ to $1.0 \times 10^{8}$ cells l$^{-1}$ in samples from $250 \mathrm{~m}$, and from $0.34 \times 10^{8}$ to $1.29 \times 10^{8}$ cells ${ }^{-1}$ in samples from $270 \mathrm{~m}$ (Fig. 4). In contrast, $\alpha$-proteobacteria in $400 \mathrm{~m}$ samples became slightly less abundant, their abundances ranging from $0.08 \times 10^{8}$ to $0.66 \times 10^{8}$ cells $\mathrm{I}^{-1}$ over time. Following $2 \mathrm{~d}$ of incubation, abundances

Fig. 3. Cluster analysis of T-RFLP patterns using the UPGMA method and Jaccard distances. The number and symbol following 'A' indicate sample depths and groups formed by cutting the dendrogram at a value of $45 \%$ information remaining, respectively. Information remaining is conceptually similar to an $\mathrm{r}^{2}$ value

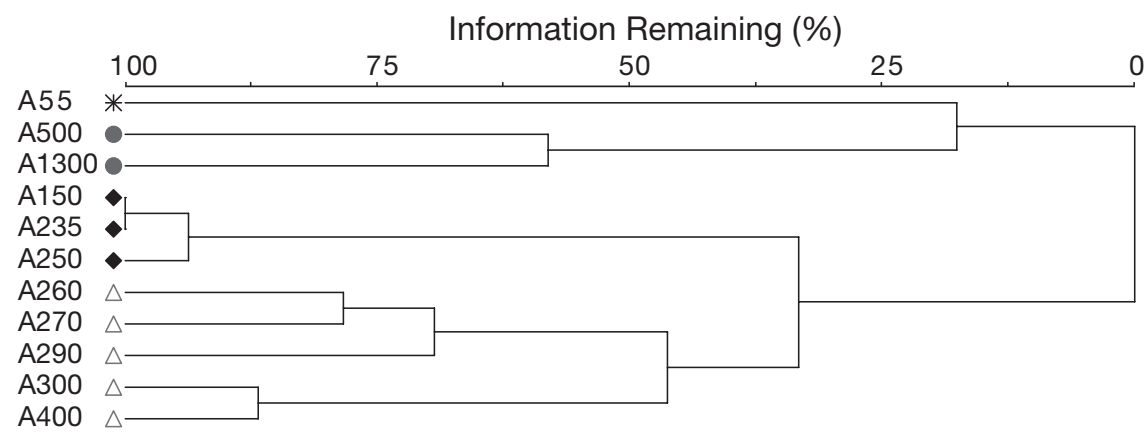






of $\alpha$-proteobacteria in control samples at all depths were significantly higher (paired $t$-test, $\mathrm{p}<0.001, \mathrm{n}=$ 9) than in predator-exclusion bottles. Abundances of $\beta$-proteobacteria from all 3 depths decreased immediately and were almost undetectable after $8 \mathrm{~d}$ in both treatments. In contrast to $\beta$-proteobacteria, $\gamma$-proteobacteria dramatically increased in all samples during incubation and became the dominant group over

Table 1. First-order rates of change $\left(k_{,} \mathrm{d}^{-1}\right)$ in abundances of selected phylogenetic bacterial groups in predator-exclusion experiments. Rates presented as control/predator-exclusion and were calculated from abundances at 0 and $2 \mathrm{~d}_{i}$ pro. $=$ proteobacteria

\begin{tabular}{|lccccc|}
\hline Depth (m) & DAPI & $\alpha$-pro. & $\beta$-pro. & $\gamma$-pro. & $\varepsilon$-pro. \\
\hline 250 & $0.27 / 0.21$ & $-0.05 /-0.53$ & $-0.26 /-0.42$ & $0.87 / 1.01$ & $0.51 / 0.40$ \\
270 & $0.34 / 0.49$ & $0.49 / 0.48$ & $-0.36 /-0.51$ & $1.08 / 1.56$ & $0.12 / 0.07$ \\
400 & $1.07 / 1.25$ & $1.04 / 1.06$ & $-0.25 /-0.22$ & $2.17 / 2.68$ & $1.41 / 1.60$ \\
\hline
\end{tabular}

time, exceeding $\sim 20$ to $45 \%$ of total cell inventories. Growth rates of $\gamma$-proteobacteria were 16 to $45 \%$ higher in predator-exclusion samples than in control samples (Table 1).

Distinct responses of $\varepsilon$-proteobacteria to predator exclusion and confinement were apparent at all 3 depths (Fig. 4). In the $250 \mathrm{~m}$ samples, $\varepsilon$-proteobacterial abundance in control bottles almost doubled within the first $2 \mathrm{~d}$, whereas significant increases in $\varepsilon$-proteobacteria were only observed in predator-exclusion bottles after $4 \mathrm{~d}$. In the $270 \mathrm{~m}$ samples, $\varepsilon$-proteobacterial abundances did not vary in the first $24 \mathrm{~h}$ and then decreased to 23 and $38 \%$ of original abundances through the remainder of the incubation in control and predator-exclusion samples, respectively. In the $400 \mathrm{~m}$ samples, $\varepsilon$-proteobacteria attained relatively high growth rates compared with 


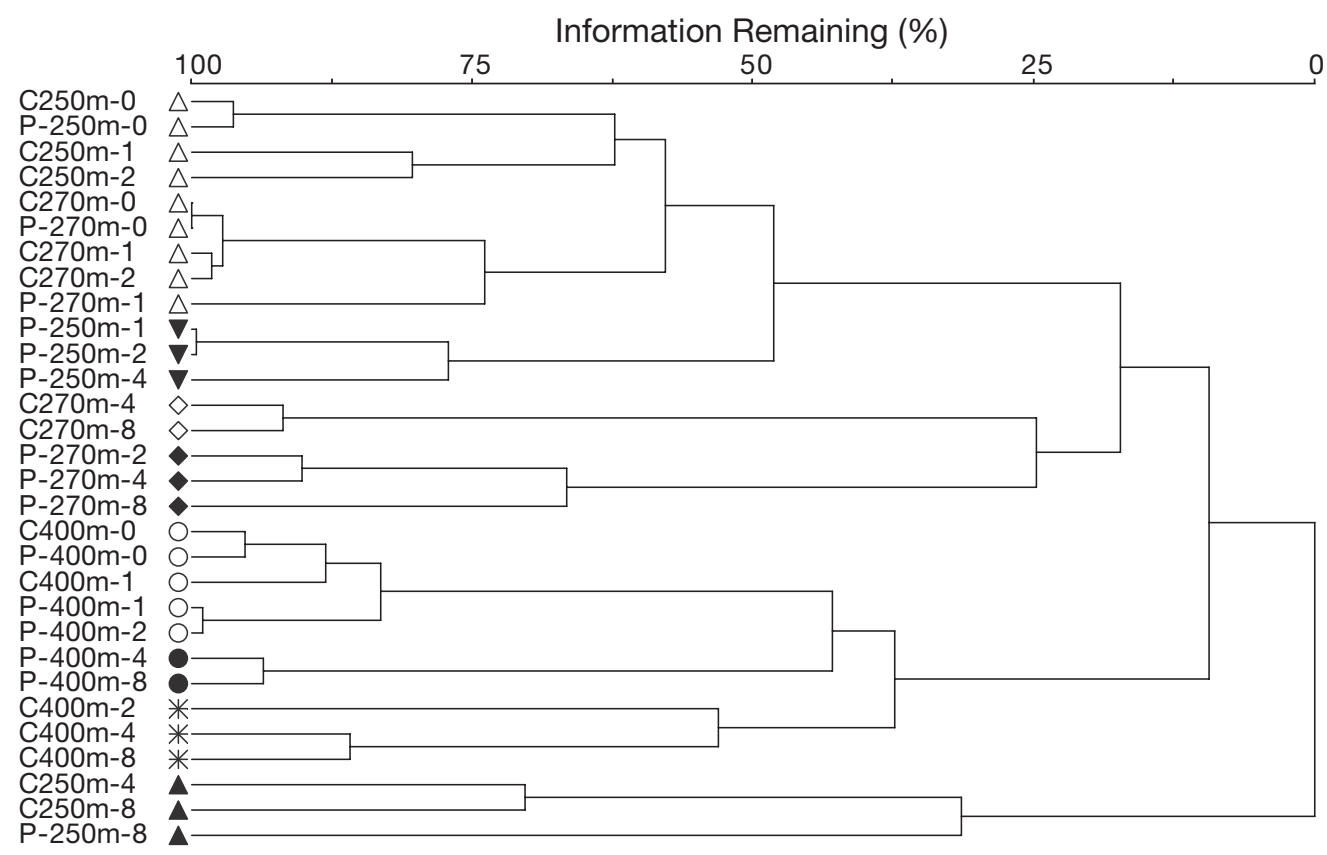

Fig. 5. Cluster analysis of T-RFLP patterns generated from predator-exclusion experiments at all depths using the UPGMA method and Jaccard distances. C and P-: control and predator-exclusion samples, respectively. The last number in each sample label indicates incubation time (d). Information remaining is conceptually similar to an $\mathrm{r}^{2}$ value

samples from the other 2 depths (Table 1). Furthermore, their growth in predator-exclusion bottles was faster (1.6 vs. $\left.1.4 \mathrm{~d}^{-1}\right)$ and lasted longer ( 4 vs. $2 \mathrm{~d}$ ) than in the controls. Overall, predation appeared to deplete populations of $\gamma$ - and $\varepsilon$-proteobacteria while allowing $\alpha$-proteobacteria to flourish. Significant declines in $\beta$ proteobacteria during incubation appear to be attributable to either limited availability of preferred substrates or superior competitive abilities of other fast-growing bacteria in both treatments.

Cluster analyses of T-RFLP patterns also illustrated that bacterial communities released from grazing pressure changed substantially at all 3 depths compared with controls (Fig. 5). T-RFLP patterns in the $t_{0}$ samples also demonstrated that prefiltration with APFA filters did not significantly alter initial community structures, because filtered and unfiltered samples clustered closely together (e.g. C250-0 and P250-0, Fig. 5). Bacterial communities were most similar among initial control samples from 250 and $270 \mathrm{~m}$ ( $>50 \%$ similarity), and least similar $(<30 \%$ similarity) between initial samples and samples incubated for more than $4 \mathrm{~d}$. Less than $50 \%$ similarity was found between controls and predator-exclusion samples from all depths after incubation (Fig. 5). Bacterial OTU richness in 250 and $400 \mathrm{~m}$ communities (with and without predators) increased between 0 and $2 \mathrm{~d}$, and decreased thereafter (Table 2). In the $270 \mathrm{~m}$ samples, OTU richness steadily decreased during incubations of both treatments.
Effects of predator exclusion were most evident in T-RFLP patterns after $2 \mathrm{~d}$, with consistently lower OTU richness in the predator-exclusion treatments than in whole water at all 3 depths (Table 2). As an example, T-RFLP patterns obtained from control and predatorexclusion treatments after $2 \mathrm{~d}$ of incubation are compared in Fig. 6. Similar results were obtained throughout the incubation period for all depths. Some OTUs persisted in control samples after $2 \mathrm{~d}$, but the abundances of several OTUs diminished to below detection (e.g. 207, 214, $217 \mathrm{bp}$ at depths of 250 and $270 \mathrm{~m} ; 124$ and $248 \mathrm{bp}$ at $400 \mathrm{~m}$ ) in the predator-exclusion treatments. In contrast, a few OTUs appeared to be unaffected by the presence or absence of predators (e.g. $227 \mathrm{bp}$ at all 3 depths). The third category of OTUs (e.g. $204 \mathrm{bp}$ at $250 \mathrm{~m}$ ) appeared to accumulate more in the predator-exclusion treatments than in controls.

Table 2. Summary of operational taxonomic unit (OTU) richness during incubation in predator-exclusion experiments

\begin{tabular}{|lllllll|}
\hline \multirow{2}{*}{ Depth $(\mathrm{m})$} & & $0 \mathrm{~d}$ & $1 \mathrm{~d}$ & $2 \mathrm{~d}$ & $4 \mathrm{~d}$ & $8 \mathrm{~d}$ \\
\hline 250 & Control & 25 & 27 & 36 & 21 & 20 \\
& Predator-exclusion & 24 & 26 & 29 & 19 & 10 \\
270 & Control & 33 & 26 & 27 & 16 & 14 \\
& Predator-exclusion & 35 & 22 & 20 & 15 & 12 \\
400 & Control & 24 & 28 & 28 & 21 & 23 \\
& Predator-exclusion & 23 & 25 & 26 & 20 & 22 \\
& & & & & & \\
\end{tabular}


Phylogenetic assignments of OTUs in the original samples

Using a series of 5 restriction endonucleases and the TReFID program, bacterial 16S rRNA gene fragments retrieved from the 250, 270, and $400 \mathrm{~m}$ DNA samples matched 1772, 1707 and 905 sequences in GenBank, respectively (Table 3). Among these, about 50 to $73 \%$ of the sequences remain unclassified to the genus level. Fragments with known affiliation were distributed into 110, 97, and 61 genera in samples from 250, 270 , and $400 \mathrm{~m}$, respectively (Table 3 ). Bacterial community compositions within 250 and $270 \mathrm{~m}$ samples were quite similar, and differed to some extent from

Fragment size (bp)

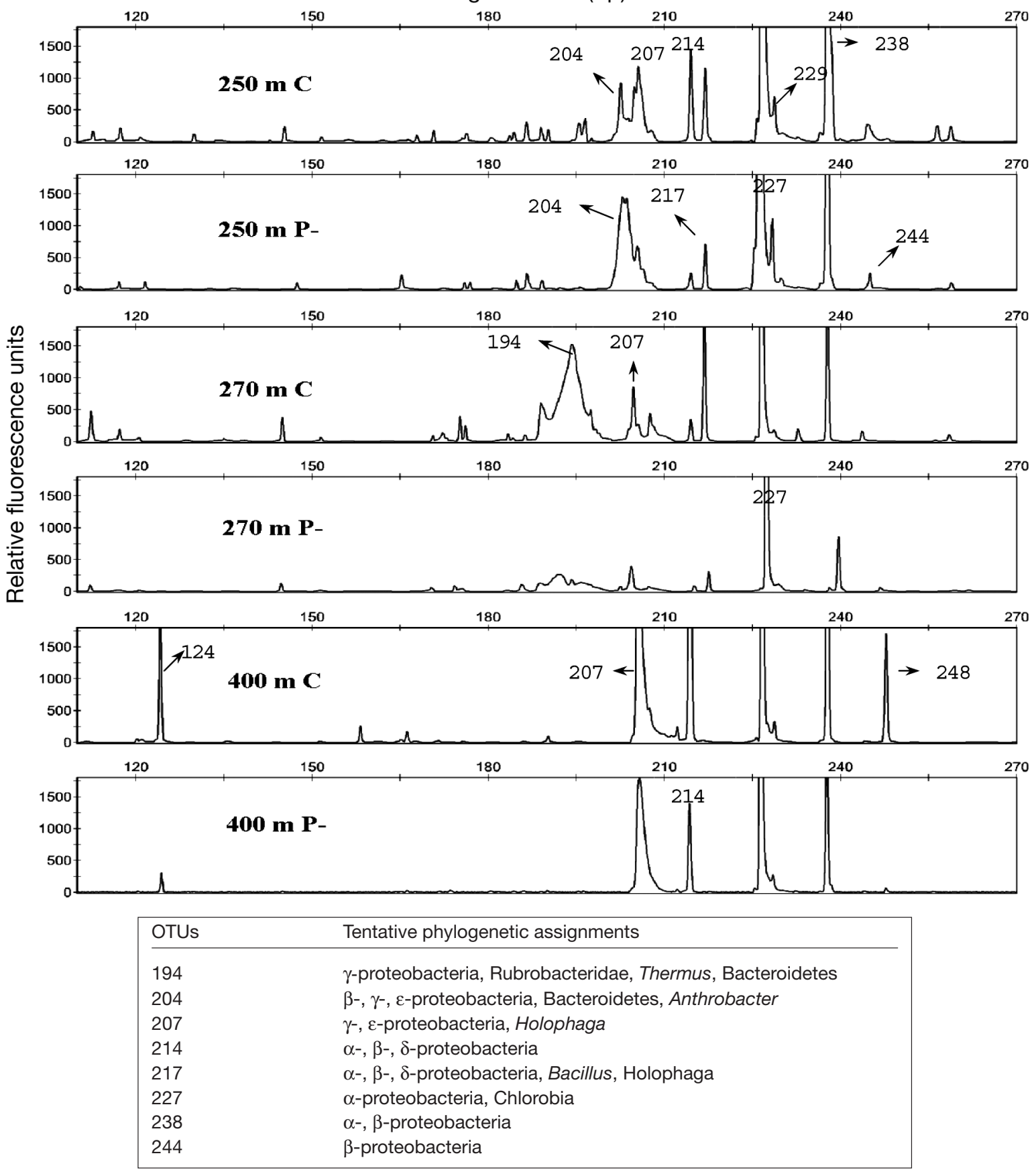

Fig. 6. T-RFLP patterns generated by Alu I restriction endonuclease digest and tentative assignments of major OTUs in predatorexclusion experiments after $2 \mathrm{~d}$ of incubation. Only the region of interest in T-RFLP patterns is presented, and fragment sizes of the OTUs (in bp) are noted next to peaks. C and P-: control and predator-exclusion samples, respectively 
those in the $400 \mathrm{~m}$ sample. For example, fragments putatively derived from Cyanobacteria and Chlorobia were present only in 250 and $270 \mathrm{~m}$ samples, while those of Aquificae and Thermotogae were present only in $400 \mathrm{~m}$ samples. Additionally, putative Planctomycetes fragments were absent from $250 \mathrm{~m}$ samples, and only apparent in 270 and $400 \mathrm{~m}$ samples. Tentative OTU assignments of major peaks that appear responsive to presence or absence of bacterivores after $2 \mathrm{~d}$ of incubation are listed in Fig. 6 . The $\alpha-, \beta-, \gamma-$, and $\varepsilon$-proteobacteria appear to be represented in the T-RFLP profiles. However, most of their OTUs, such as the 194, 204, and 217 bp fragments, can be assigned to several different bacterial taxa. This apparent limitation prevents specific assignment of the OTUs to certain bacterial species or phylogenetic groups.

\section{Group-specific assimilation of ${ }^{3} \mathrm{H}$-leucine}

In order to establish whether taxonomic composition of metabolically active bacteria shifts during incubations with and without predators, assemblages provided with ${ }^{3} \mathrm{H}$-leucine for $24 \mathrm{~h}$ were surveyed by MICRO-FISH. No silver grain-positive cells were observed in the killed controls, indicating that the radioactive substrate was assimilated by living cells rather than adsorbed to the cell surface. In the $270 \mathrm{~m}$ samples, cells assimilating ${ }^{3} \mathrm{H}$-leucine were detected in $30 \%$ of DAPI counts in controls and $27 \%$ in the preda- tor-exclusion treatment. Among ${ }^{3} \mathrm{H}$-leucine-assimilating cells in control samples, $\alpha-, \gamma$-, and $\varepsilon$-proteobacteria accounted for 12,38 , and $14 \%$, respectively. Taxonomic distributions of ${ }^{3} \mathrm{H}$-leucine-assimilating cells in the predator-exclusion treatments did not differ detectably from controls (paired $t$-test, $\mathrm{p}=0.9, \mathrm{n}=3$ ). Assimilation of ${ }^{3} \mathrm{H}$-leucine was undetectable among any $\beta$-proteobacteria, even though their cells accounted for significant proportions of total cell counts in all samples. This group was either metabolically inactive during the incubations or simply incapable of leucine uptake.

\section{DISCUSSION}

\section{Evaluation of experimental design and methods}

The simultaneous application of FISH and T-RFLP obviously gives a more complete assessment of bacterial community dynamics than that provided by either alone. The FISH probes selected accounted for $74 \pm$ $17 \%$ of EUB338-positive cells, indicating that most bacterial lineages occurring in Cariaco Basin samples were detected by this limited set of probes. Cytophaga-Flavobacteria-Bacteroides and $\delta$-proteobacteria were omitted in this assessment because they accounted for $<2 \%$ of total prokaryotic cells measured by FISH in our samples (data not shown); however, they can potentially be important elsewhere (Glöckner et al.

Table 3. Summary of tentative bacterial taxon assignments for OTUs in samples from 3 depths using the TReFID database. T-RFLP patterns were constructed from 5 restriction endonuclease digests of each sample (see 'Materials and methods'). na: non applicable

\begin{tabular}{|c|c|c|c|c|c|c|}
\hline \multirow[t]{3}{*}{ Phyla or class } & \multirow{2}{*}{\multicolumn{2}{|c|}{$\overline{250 \mathrm{~m}} \mathrm{~N}$}} & er of spec & es and ge & & \\
\hline & & & \multicolumn{2}{|c|}{$270 \mathrm{~m}$} & \multicolumn{2}{|c|}{$400 \mathrm{~m}$} \\
\hline & Genera & Species & Genera & Species & Genera & Species \\
\hline \multicolumn{7}{|l|}{ Proteobacteria } \\
\hline$\alpha$ & 22 & 154 & 11 & 22 & 9 & 20 \\
\hline$\beta$ & 16 & 81 & 13 & 93 & 4 & 9 \\
\hline$\gamma$ & 18 & 131 & 15 & 125 & 20 & 84 \\
\hline$\delta$ & 2 & 4 & 1 & 2 & 3 & 4 \\
\hline$\varepsilon$ & 3 & 45 & 3 & 40 & 2 & 8 \\
\hline Actinobacteria & 15 & 227 & 27 & 392 & 4 & 49 \\
\hline Aquificae & 0 & 0 & 0 & 0 & 2 & 3 \\
\hline Bacilli & 7 & 13 & 6 & 42 & 6 & 36 \\
\hline Bacteroidetes & 9 & 21 & 5 & 16 & 5 & 16 \\
\hline Chlorobia & 3 & 8 & 2 & 6 & 0 & 0 \\
\hline Cyanobacteria & 6 & 12 & 5 & 35 & 0 & 0 \\
\hline Deinococcus-Thermus & 2 & 10 & 2 & 36 & 1 & 1 \\
\hline Mollicutes & 3 & 34 & 3 & 33 & 2 & 7 \\
\hline Spirochaetes & 4 & 11 & 4 & 16 & 2 & 3 \\
\hline Thermotogae & 0 & 0 & 0 & 0 & 1 & 6 \\
\hline No. of species/genera matched (classified in GenBank) & 110 & 751 & 97 & 858 & 61 & 246 \\
\hline No. of organisms unclassified to genus level in GenBank & na & 1021 & na & 849 & na & 659 \\
\hline Total no. of matches & na & 1772 & na & 1707 & na & 905 \\
\hline
\end{tabular}


1999). While not providing a complete inventory or very high taxonomic resolution, the FISH analysis employed here did provide useful and consistent information on community dynamics.

Quantitative interpretation of the T-RFLP results must be done cautiously because PCR can introduce amplification biases (Suzuki \& Giovannoni 1996, Polz \& Cavanaugh 1998, Crosby \& Criddle 2003). We circumvented this issue to an extent by using the absence or presence of OTUs and not peak heights for the numerical analysis. We also recognize that some rarer taxa generally escape detection by this technique. Hence, TRFLP patterns probably reflect dominant OTUs but disregard rarer taxa in the bacterial assemblages. The output from TReFID analysis provided an approximate and sometimes ambiguous characterization of bacterial phylogenetic composition in our communities. Theoretically, it is possible to retrieve bacterial community composition down to the genus level if a sufficient combination of enzyme digests ( $\geq 9$ restriction endonucleases) is employed (Rosch \& Bothe 2005). Nevertheless, some erroneous assignments may still be made as a result of pseudo-terminal restriction fragment production (Egert \& Friedrich 2003) and occasional errors in fragment-size determination (Liu et al. 1997, Clement et al. 1998, Marsh et al. 2000, Osborn et al. 2000). Hence, construction of clone libraries or microarray analysis definitely have higher resolving power and may be more robust (DeSantis et al. 2003) than T-RFLP and FISH.

Time-course experiments with and without predators were conducted to investigate the influence of bacterivores on the composition of microaerophilic and anaerobic microbial communities. The recovery efficiency of prokaryotic cells during prefiltration steps decreased slightly with depth owing to varying size structure of bacterial communities at different depths of the Cariaco Basin (G. T. Taylor unpubl. data). Whether the requisite prefiltration step significantly altered initial bacterial community composition from that of control samples cannot be totally resolved with the existing data. However, similarities in FISH and TRFLP profiles for control and predator-exclusion treatments at the initiation of incubations suggest minimal alteration of basic community composition. Furthermore, MICRO-FISH results are essentially indistinguishable between treatments, indicating that both treatments share similar metabolically active populations. One possible artifact is that water samples might have been contaminated by small amounts of oxygen during incubation, thereby altering community metabolism. However, previous experimentation with the redox-indicating dye, resazurin, demonstrated that oxygen penetration into this type of incubation vial is barely detectable. Thus, oxygenation of anoxic samples does not appear to be a serious concern.

\section{Vertical redox gradients impose structure on microbial communities}

Both FISH and T-RFLP analyses provided clear evidence of a pronounced shift in bacterial community composition across the redoxcline in the Cariaco Basin, as well as in the Black Sea (Vetriani et al. 2003, Lin et al. 2006). The present data show that several OTUs that dominate oxic waters became lower-ranking fragments in oxygen-depleted waters. In contrast, some OTUs that are rare above the $\mathrm{O}_{2} / \mathrm{H}_{2} \mathrm{~S}$ interface became prevalent below the interface. The T-RFLP and FISH results are consistent with the hypothesis that changing redox regimes through the water column alter selective pressures on microorganisms, promoting and inhibiting different members of the bacterial community. Observed distribution patterns likely reflect gradients in energy substrates and oxidants, niche adaptation and possibly sulfide tolerance of different guilds of bacteria in the Cariaco Basin. Linking specific OTUs or species with biogeochemical processes and environmental variables is a challenge awaiting further research.

\section{Resource availability and species competition}

Generally, predation in the water column leads to changes in species competition and efficiency of resource cycling (Pomeroy 1974, Sieburth 1981, Caron \& Goldman 1990, Pernthaler 2005). The present results indicate that bacterial community size tended to stabilize at different levels among the depths sampled. Apparently, the maximum cell density reached during incubation was more dependent on the resource availability (e.g. reductants and oxidants) than on grazing pressure, because changes in bacterial abundance over time in both treatments were larger than differences between treatments. Presumably, availability of limiting resources such as dissolved organic matter, other electron donors, and electron acceptors determined bacterial abundance and composition, consistent with previous observations (Azam et al. 1983, Fuchs et al. 2000, Ho et al. 2004).

FISH results also indicated that resource availability had a strong influence on the taxonomic composition of the bacterial community that developed. Water from $270 \mathrm{~m}$ contained high initial abundances of $\varepsilon$-proteobacteria and supported their growth on the first day, but populations declined after the second day, suggesting that insufficient resources were available to support further growth. The $\gamma$-proteobacteria contributed minor proportions to initial bacterial assemblages and became more dominant after incubation. We argue that fast growing $\gamma$-proteobacteria might be 
favored at some depths in the Cariaco Basin, and are a preferred target of selective predation (Beardsley et al. 2003). Growth of $\alpha$ - and $\beta$-proteobacteria was slow and inconsistent, and ceased at very low abundances, resulting in declining relative abundances over time.

One possible explanation for declines in $\beta$-proteobacterial populations (especially in 250 and $270 \mathrm{~m}$ samples) is that growth substrates for this group were not available during incubations and that they consequently starved. This hypothesis is supported by their inability to assimilate ${ }^{3} \mathrm{H}$-leucine, which at least confirms that this group does not utilize a common amino acid. These $\beta$-proteobacteria could be obligate chemoautotrophs, methylotrophs, or a relict of a $\beta$-proteobacterial populations imported from neighboring environments. This last speculation is supported by the finding of significant seasonality in abundances of $\beta$ proteobacteria in the Cariaco Basin (X. Lin unpubl. data). The rapidity of their disappearance from all treatments is puzzling. We can only speculate that these cells lysed (autolytically or virally induced), adhered to the walls of the incubation bottles or escaped detection as rRNA degraded. None of these hypotheses can be adequately evaluated with existing data. Overall, FISH results illustrated that there was a succession of bacterial populations during incubations, consistent with observations in studies conducted in oxic waters (Fuchs et al. 2000, Massana et al. 2001). Bacterial communities observed here are just a snapshot in time and space, and are subject to changing nutrient environments, even in this seemingly stable environment.

\section{Influence of bacterivores}

Previous observations in the Cariaco Basin have consistently revealed enrichments in flagellated and ciliated protistan inventories within the redoxcline, and declining abundances below $450 \mathrm{~m}$ (Taylor et al. 2003, 2006). Flagellated protistan abundances within the Cariaco Basin redoxcline were relatively high during this study $\left(15 \times 10^{5}\right.$ to $30 \times 10^{5}$ cells $\left.\mathrm{l}^{-1}\right)$ but were not unusual for this environment, which has supported between $0.4 \times 10^{5}$ and $50 \times 10^{5}$ cells $1^{-1}$ over the course of the CARIACO time-series study (1995 to 2006) (G. T. Taylor unpubl. data). The limited protistan phylogenetic database available for the Cariaco Basin suggests that many taxa are closely affiliated with described shallow-water, anaerobic species, and that novel, deeply divergent clades are also represented (Stoeck et al. 2003). Heterotrophic protists (flagellated and ciliated) have been reported from microxic and anoxic layers in a variety of other stratified aquatic environments (Fenchel et al. 1990, 1995, Zubkov et al. 1992, Guhl et al. 1996, Behnke et al. 2006). Vertical profiles from the Black Sea, the Framvaren, Mariager and Virksund fjords and assorted anoxic lakes have all revealed enhanced inventories of protists across the $\mathrm{O}_{2} / \mathrm{H}_{2} \mathrm{~S}$ interface, and many taxa are recognized as bacterivores (e.g. Fenchel et al. 1990, Guhl et al. 1996). Given the biogeochemical and microbiological similarities between these systems and the Cariaco Basin, we contend that many of the protists enumerated in the Cariaco Basin's redoxcline are likely to be bacterivores.

We interpreted quantitative differences (revealed by FISH) in representation of each bacterial group within controls and predator-exclusion treatments to be a consequence of grazing pressure. For example, $\gamma$-proteobacteria had higher net growth rates and abundances in predator-exclusion incubations than in controls, suggesting that this group is selectively controlled by bacterivores in unaltered samples. This is consistent with previous findings that bacterivorous protozoa selectively graze on actively growing cells (Sherr et al. 1992). However, obvious shifts in cell morphotypes (such as development of filamentous bacteria) as a consequence of high or low grazing pressure were not observed (data not shown), as has been previously observed in pelagic ecosystems (Posch et al. 1999, Pernthaler et al. 2001, Vazquez-Dominguez et al. 2005).

Ecological theory predicts that processes causing mortality (bacterivory and viral lysis) help maintain species richness within a community by culling the most actively growing populations (Thingstad \& Lignell 1997, Šimek et al. 2001, Pernthaler 2005). In effect, selective mortality partially relieves interspecific resource competition and allows weaker competitors to proliferate. Thus, OTU richness should be lower in predator-exclusion samples than in controls. In fact, predator exclusion did lead to significant reduction in bacterial OTU richness within T-RFLP profiles compared with controls. Only a few OTUs showed a neutral response to predator exclusion, while a few others flourished under reduced grazing pressure. Trends in OTU richness derived from T-RFLP patterns are quite consistent with the FISH findings, in which predator exclusion led to predominance of $\gamma$ and $\varepsilon$-proteobaterial populations. As discussed above, the observed T-RFLP pattern may reflect only dominant OTUs. It is conceivable that apparent OTU richness in samples with low OTU evenness would be lower than in samples with relatively high taxon evenness if the same amount of restriction digest is used for fragment determination. Observing finer-scale effects of bacterivore selectivity on community composition is precluded because the 16S rRNA techniques employed are of relatively low taxonomic resolution (Sherr \& Sherr 2002, Pernthaler 2005). 


\section{Confinement vs. predator-exclusion effects}

Confinement effects on prokaryotic communities, such as stimulated metabolic activity of some populations and declining bacterial OTU richness over time, have been previously reported (Sherr et al. 1999, Suzuki 1999, Massana et al. 2001). Similar trends were observed in our incubation experiments. In predatorexclusion experiments with samples from 250 and $400 \mathrm{~m}$, OTU richness on average increased by 33 and $15 \%$ in the first $2 \mathrm{~d}$ and decreased by 135 and $20 \%$ in the last $6 \mathrm{~d}$. OTU richness at $270 \mathrm{~m}$ decreased steadily from the beginning in both control and predator-exclusion samples. In contrast, bacterial populations in the incubation vials did not all grow at the same rate, as revealed by FISH. Rather, some populations grew faster than others and eventually dominated the final assemblage. These populations are not necessarily those that were most abundant at the start of the experiment, a trend also seen in oxic waters (Massana et al. 2001). Assimilation activities measured by MICRO-FISH during bottle incubations corresponded well to fast-growing populations such as $\gamma$-proteobacteria and declining populations like $\beta$-proteobacteria (Table 1). Some authors argue that populations proliferating during bottle incubations were the those actively growing in situ but maintained at low abundances by grazing pressure (Suzuki 1999, Massana et al. 2001). Therefore, confinement may significantly alter community composition during time course experiments and likely bias characterization of microbial community structure (Massana et al. 2001).

\section{Carbon metabolism of major bacterial populations}

To gain more insight into different phylogenetic groups, their metabolic activities with and without bacterivores were investigated using MICRO-FISH. In this experiment, the proportion of total cells detected by the EUB338 probe was roughly 2.5 times the fraction of DAPI counts that were both EUB338and silver grain-positive. Karner \& Fuhrman (1997) demonstrated that marine bacterioplankton that assimilate radioactive substrates are usually FISH probe-positive cells. In the present study, the proportion of probe-positive but ${ }^{3} \mathrm{H}$-leucine inactive cells was much higher than that observed by Karner \& Fuhrman (1997), suggesting that many Cariaco Basin cells were either heterotrophs incapable of leucine assimilation or obligate chemoautotrophs. Silver grain-positive cells accounted for only 43,61 and $17 \%$ of probe-positive cells for $\alpha-, \gamma-$, and $\varepsilon$-proteobacteria, respectively. The low correspondence between the 2 methods for $\varepsilon$-proteobacteria suggests that members of this group are more likely to be chemoautotrophic than are $\alpha$ - and $\gamma$-proteobacteria. In addition, active growth of $\varepsilon$-proteobacteria was measured in the incubations, thereby excluding the possibility that EPS682-positive cells were merely inactive cells with high ribosomal contents. This finding is consistent with previous assertions that $\varepsilon$-proteobacteria contribute the bulk of chemoautotrophic production in the chemocline of suboxic and anoxic waters (Madrid et al. 2001, Vetriani et al. 2003, Labrenz et al. 2005, Taylor et al. 2006).

Finally, the lack of detectable grazing effects on ${ }^{3} \mathrm{H}$ leucine assimilation activity may imply that growthlimiting resources are more important than predation in controlling biomass accumulation of different phylogenetic groups in the Cariaco Basin redoxcline. Alternatively, the influence of bacterivory in culling metabolically active prey may not have been detectable during the short duration of incubation (only $1 \mathrm{~d}$ for MICRO-FISH experiment) because we only observed significant changes in bacterial assemblages between control and predator-exclusion treatments after $\geq 2 \mathrm{~d}$ of incubation. A similar finding was reported in a study on the effect of protistan bacterivory on coastal bacterioplankton diversity, which showed that significant differences between filtered water samples and controls were only evident after more than $24 \mathrm{~h}$ of incubation (Suzuki 1999).

\section{CONCLUSIONS}

Both FISH profiles and T-RFLP patterns clearly indicated that bacterial abundances and community composition shift with depth. Differences in responses of either specific bacterial groups or individual OTUs to predator exclusion were detected by FISH and T-RFLP techniques, and this influence differed among depths. Confinement can also significantly influence bacterial community composition during incubations. Owing to inherent limitations of PCR-based T-RFLP techniques and in silico TReFID analyses, it was not possible to link each unique T-RF with specific bacteria in this study, which makes it difficult to further assess the consistency of results produced by these 2 independent techniques.

In contrast, MICRO-FISH identified active heterotrophic bacterial clades in the redoxcline, providing insight into the ecological roles of different phylogenetic bacterial groups. Large proportions of $\varepsilon$-proteobacteria in the prokaryotic assemblages were incapable of ${ }^{3} \mathrm{H}$-leucine assimilation but readily shown by oligonucleotide probes to be actively growing, which suggests that many of these $\varepsilon$-proteobacteria are chemoautotrophs. 
Acknowledgements. We thank the captain and crew of BO 'Hermano Gines' and the staff of Fundacion La Salle de Ciencias Naturales for their assistance during field work in Venezuela. We are very grateful to Dane Percy for providing sulfide data, and to Jackie Collier and Michael Doall for assistance with T-RFLP analyses, which were performed in the NSF-funded MEAD Laboratory in the Department of Ecology and Evolution at Stony Brook University. This research was supported by grants from NSF (OCE 03-26175 and MCB0347811 to G.T.T. and M.I.S.) and from Venezuela FONACIT (No. 2000001702). This publication represents Marine Sciences Research Center Contribution No. 1333.

\section{LITERATURE CITED}

Amann RI, Binder BJ, Olson RJ, Chisholm SW, Devereux R, Stahl DA (1990) Combination of $16 \mathrm{~S}$ ribosomal-RNAtargeted oligonucleotide probes with flow-cytometry for analyzing mixed microbial populations. Appl Environ Microbiol 56:1919-1925

Azam F, Fenchel T, Field JG, Gray JS, Meyerreil LA, Thingstad F (1983) The ecological role of water-column microbes in the sea. Mar Ecol Prog Ser 10:257-263

Beardsley C, Pernthaler J, Wosniok W, Amann R (2003) Are readily culturable bacteria in coastal North Sea waters suppressed by selective grazing mortality? Appl Environ Microbiol 69:2624-2630

Behnke A, Bunge J, Barger K, Breiner HW, Alla V, Stoeck T (2006) Microeukaryote community patterns along an O2/H2S gradient in a supersulfidic anoxic fjord (Framvaren, Norway). Appl Environ Microbiol 72:3626-3636

Biagini G, Finlay B, Lloyd D (1998) Protozoan stimulation of anaerobic microbial activity: enhancement of the rate of terminal decomposition of organic matter. FEMS Microbiol Ecol 27:1-8

Blackwood C, Marsh T, Kim S, Paul E (2003) Terminal restriction fragment length polymorphism data analysis for quantitative comparison of microbial communities. Appl Environ Microbiol 69:926-932

Carman KR (1993) Microautoradiographic detection of microbial activity. In: Kemp PE, Sherr BE, Sherr EB, Cole JJ (eds) Handbook of methods in aquatic microbial ecology. Lewis Publishers, Boca Raton, FL, p 397-404

Caron DA, Goldman JC (1990) Protozoan nutrient regeneration. In: Capriulo GM (ed) Ecology of marine protozoa. Oxford University Press, New York, p 283-306

Clement B, Kehl L, DeBord K, Kitts C (1998) Terminal restriction fragment patterns (TRFPs), a rapid, PCR-based method for the comparison of complex bacterial communities. J Microbiol Methods 31:135-142

Crosby L, Criddle C (2003) Understanding bias in microbial community analysis techniques due to rrn operon copy number heterogeneity. Biotechniques 34:790

DeSantis T, Dubosarskiy I, Murray S, Andersen G (2003) Comprehensive aligned sequence construction for automated design of effective probes (CASCADE-P) using 16S rDNA. Bioinformatics 19:1461-1468

Egert M, Friedrich MW (2003) Formation of pseudo-terminal restriction fragments, a PCR-related bias affecting terminal restriction fragment length polymorphism analysis of microbial community structure. Appl Environ Microbiol 69:2555-2562

Fenchel T, Finlay BJ (1994) The evolution of life without oxygen. Am Sci 82:22-29

Fenchel T, Kristensen LD, Rasmussen L (1990) Water column anoxia-vertical zonation of planktonic protozoa. Mar
Ecol Prog Ser 62:1-10

Fenchel T, Bernard C, Esteban G, Finlay BJ, Hansen PJ, Iversen N (1995) Microbial diversity and activity in a Danish fjord with anoxic deep water. Ophelia 43:45-100

Fuchs B, Zubkov M, Sahm K, Burkill P, Amann R (2000) Changes in community composition during dilution cultures of marine bacterioplankton as assessed by flow cytometric and molecular biological techniques. Environ Microbiol 2:191-201

Glöckner F, Fuchs B, Amann R (1999) Bacterioplankton compositions of lakes and oceans: a first comparison based on fluorescence in situ hybridization. Appl Environ Microbiol 65:3721-3726

Guhl BE, Finlay BJ, Schink B (1996) Comparison of ciliate communities in the anoxic hypolimnia of three lakes: general features and the influence of lake characteristics. J Plankton Res 18:335-353

Hahn M, Hofle M (2001) Grazing of protozoa and its effect on populations of aquatic bacteria. FEMS Microbiol Ecol 35: 113-121

Ho T, Taylor G, Astor Y, Varela R, Muller-Karger F, Scranton M (2004) Vertical and temporal variability of redox zonation in the water column of the Cariaco Basin: implications for organic carbon oxidation pathways. Mar Chem 86:89-104

Karner M, Fuhrman J (1997) Determination of active marine bacterioplankton: a comparison of universal 16S rRNA probes, autoradiography, and nucleoid staining. Appl Environ Microbiol 63:1208-1213

Kent A, Smith D, Benson B, Triplett E (2003) Web-based phylogenetic assignment tool for analysis of terminal restriction fragment length polymorphism profiles of microbial communities. Appl Environ Microbiol 69:6768-6776

Labrenz M, Jost G, Pohl C, Beckmann S, Martens-Habbena W, Jurgens K (2005) Impact of different in vitro electron donor/acceptor conditions on potential chemolithoautotrophic communities from marine pelagic redoxclines. Appl Environ Microbiol 71:6664-6672

Lin X, Wakeham S, Putnam I, Astor Y, Scranton M, Chistoserdov A, Taylor G (2006) Vertical distributions of prokaryotic assemblages in the anoxic Cariaco Basin and Black Sea compared using fluorescence in situ hybridization (FISH). Appl Environ Microbiol 72:2679-2690

Liu W, Marsh T, Cheng H, Forney L (1997) Characterization of microbial diversity by determining terminal restriction fragment length polymorphisms of genes encoding 16S rRNA. Appl Environ Microbiol 63:4516-4522

Madrid V, Taylor G, Scranton M, Chistoserdov A (2001) Phylogenetic diversity of bacterial and archaeal communities in the anoxic zone of the Cariaco Basin. Appl Environ Microbiol 67:1663-1674

Manz W, Amann RI, Ludwig W, Wagner M, Schleifer KH (1992) Phylogenetic oligodeoxynucleotide probes for the major subclasses of proteobacteria-problems and solutions. Syst Appl Microbiol 15:593-600

Marchesi J, Sato T, Weightman A, Martin T, Fry J, Hiom S, Dymock D, Wade W (1998) Design and evaluation of useful bacterium-specific PCR primers that amplify genes coding for bacterial 16S rRNA. Appl Environ Microbiol 64: 795-799

Marsh T, Saxman P, Cole J, Tiedje J (2000) Terminal restriction fragment length polymorphism analysis program, a web-based research tool for microbial community analysis. Appl Environ Microbiol 66:3616-3620

Massana R, Jürgens K (2003) Composition and population dynamics of planktonic bacteria and bacterivorous flagellates in seawater chemostat cultures. Aquat Microb Ecol $32: 11-22$ 
Massana R, Pedros-Alio C, Casamayor E, Gasol J (2001) Changes in marine bacterioplankton phylogenetic composition during incubations designed to measure biogeochemically significant parameters. Limnol Oceanogr 46: $1181-1188$

McCune B, Grace JB (2002) Analysis of ecological communities. MJM Software Design, Gleneden Beach, OR

Muller-Karger F, Varela R, Thunell R, Scranton $M$ and 7 others (2001) Annual cycle of primary production in the Cariaco Basin: response to upwelling and implications for vertical export. J Geophys Res Oceans 106: 4527-4542

Neef A (1997) Anwendung der in situ Einzelzell-Identifizierung von Bakterien zur Populations Analyse in komplexen mikrobiellen Biozönosen. PhD thesis, Technische Universität München

Osborn AM, Moore ERB, Timmis KN (2000) An evaluation of terminal-restriction fragment length polymorphism ( $\mathrm{T}$ RFLP) analysis for the study of microbial community structure and dynamics. Environ Microbiol 2:39-50

Pedros-Alio C, Calderon-Paz J, Gasol J (2000) Comparative analysis shows that bacterivory, not viral lysis, controls the abundance of heterotrophic prokaryotic plankton. FEMS Microbiol Ecol 32:157-165

Pernthaler J (2005) Predation on prokaryotes in the water column and its ecological implications. Nature Rev Microbiol 3:537-546

Pernthaler J, Posch T, Šimek K, Vrba J and 5 others (2001) Predator-specific enrichment of actinobacteria from a cosmopolitan freshwater clade in mixed continuous culture. Appl Environ Microbiol 67:2145-2155

Polz M, Cavanaugh C (1998) Bias in template-to-product ratios in multitemplate PCR. Appl Environ Microbiol 64: $3724-3730$

Pomeroy LR (1974) The ocean's food web: a changing paradigm. BioScience 24:499-504

Porter K, Feig Y (1980) The use of DAPI for identification and counting aquatic microflora. Limnol Oceanogr 25:943-948

Posch T, Šimek K, Vrba J, Pernthaler S, Nedoma J, Sattler B, Sonntag B, Psenner R (1999) Predator-induced changes of bacterial size-structure and productivity studied on an experimental microbial community. Aquat Microb Ecol 18: 235-246

Richards FA (1975) The Cariaco Basin (Trench). Oceanogr Mar Biol Annu Rev 13:11-67

Rosch C, Bothe H (2005) Improved assessment of denitrifying, $\mathrm{N}$-2-fixing, and total-community bacteria by terminal restriction fragment length polymorphism analysis using multiple restriction enzymes. Appl Environ Microbiol 71: 2026-2035

Sherr B, Sherr E, McDaniel J (1992) Effect of protistan grazing on the frequency of dividing cells in bacterioplankton assemblages. Appl Environ Microbiol 58:2381-2385

Sherr E, Sherr B (2002) Significance of predation by protists in aquatic microbial food webs. Antonie Leeuwenhoek Int J Gen Mol Microbiol 81:293-308

Sherr EB, Sherr BF, Sigmon CT (1999) Activity of marine bac-

Editorial responsibility: Bess Ward,

Princeton, New Jersey, USA teria under incubated and in situ conditions. Aquat Microb Ecol 20:213-223

Sieburth JMN (1981) Protozoan bacterivory in pelagic marine waters. In: Hobbie J, Williams PJleB (eds) Heterotrophic activity in the sea, Vol 15. Plenum Press, New York, p 405-444

Šimek K, Pernthaler J, Weinbauer M, Hornak K, Dolan J, Nedoma J, Masin M, Amann R (2001) Changes in bacterial community composition and dynamics and viral mortality rates associated with enhanced flagellate grazing in a mesoeutrophic reservoir. Appl Environ Microbiol 67: $2723-2733$

Stoeck T, Taylor G, Epstein S (2003) Novel eukaryotes from the permanently anoxic Cariaco Basin (Caribbean Sea). Appl Environ Microbiol 69:5656-5663

Suzuki M (1999) Effect of protistan bacterivory on coastal bacterioplankton diversity. Aquat Microb Ecol 20:261-272

Suzuki M, Giovannoni S (1996) Bias caused by template annealing in the amplification of mixtures of 16S rRNA genes by PCR. Appl Environ Microbiol 62:625-630

Suzuki M, Preston C, Chavez F, DeLong E (2001) Quantitative mapping of bacterioplankton populations in seawater: field tests across an upwelling plume in Monterey Bay. Aquat Microb Ecol 24:117-127

Taylor G, Iabichella M, Ho T, Scranton M, Thunell R, MullerKarger F, Varela R (2001) Chemoautotrophy in the redox transition zone of the Cariaco Basin: a significant midwater source of organic carbon production. Limnol Oceanogr 46:148-163

Taylor G, Hein C, Iabichella M (2003) Temporal variations in viral distributions in the anoxic Cariaco Basin. Aquat Microb Ecol 30:103-116

Taylor GT, Iabichella M, Varela R, Muller-Karger F, Lin X, Scranton MI (2006) Microbial ecology of the Cariaco Basin's redoxcline: the U.S.-Venezuela CARIACO times series program. In: Neretin L (ed) Past and present water column anoxia. Springer, Berlin, p 473-499

Thingstad T, Lignell R (1997) Theoretical models for the control of bacterial growth rate, abundance, diversity and carbon demand. Aquat Microb Ecol 13:19-27

Torsvik V, Ovreas L, Thingstad T (2002) Prokaryotic diversity - magnitude, dynamics, and controlling factors. Science 296:1064-1066

Vazquez-Dominguez E, Casamayor E, Catala P, Lebaron P (2005) Different marine heterotrophic nanoflagellates affect differentially the composition of enriched bacterial communities. Microb Ecol 49:474-485

Vetriani C, Tran H, Kerkhof L (2003) Fingerprinting microbial assemblages from the oxic/anoxic chemocline of the Black Sea. Appl Environ Microbiol 69:6481-6488

Wallner G, Amann R, Beisker W (1993) Optimizing fluorescent in situ hybridization with ribosomal-RNA-targeted oligonucleotide probes for flow cytometric identification of microorganisms. Cytometry 14:136-143

Zubkov M, Sazhin A, Flint M (1992) The microplankton organisms at the oxic-anoxic interface in the pelagial of the Black Sea. FEMS Microbiol Lett 101:245-250

Submitted: May 3, 2006; Accepted: February 23, 2007

Proofs received from author(s): March 28, 2007 